\title{
Evaluation of Mango (Mangifera indica L.) Cultivars for Flowering, Fruiting and Yield Attributes
}

\author{
T. S. Hada*and A. K. Singh
}

Dept. of Horticulture, Institute of Agricultural Sciences, Banaras Hindu University Varanasi, Uttar Pradesh (221 005), India

\section{Corresponding Author}

T. S. Hada

e-mail: tejrajshada@gmail.com

\author{
Article History \\ Article ID: AR1811a \\ Received in $3^{\text {rd }}$ May, 2017 \\ Received in revised form $29^{\text {th }}$ June, 2017 \\ Accepted in final form $4^{\text {th }}$ August, 2017
}

\begin{abstract}
A field experiment was conducted to investigate the flowering, fruiting and yield attributes of some mango cultivars for the years $2014-15$ and 2015-16. Outcome of the present research work revealed that the date of panicle emergence in different mango cultivars varied in both the years. It was observed that the panicle emergence was earliest in Gulabkhas and late in Fazli in both the years. Chausa produced maximum panicle length $(35.19 \mathrm{~cm})$ and breadth $(24.76 \mathrm{~cm})$. In the year 2014-15, earliest flowering was noted in Gulabkhas (Feb 17-Feb 26) and in the year 2015-16, earliest flowering was observed in Bombai (Feb 20-Feb 28) while, flowering was very late in Sepiya for both the years. Maximum number of flowers was observed in Langra (1839.13) while, minimum number of flowers was recorded in Amrapali (954.75). The duration of flowering varied from 22.50-36.00 days in different mango cultivars. Maximum value in terms of days was observed with Sepiya (39 days) while it was minimum (22.50 days) in case of Alphonso. The data revealed that date of fruit set ranged from $11^{\text {th }}-8^{\text {th }}$ April. Earliest fruit setting was observed in Bombai $\left(12^{\text {th }}-16^{\text {th }}\right.$ March) during the year $2014-15$ while, earliest fruit setting was noted in Gulabkhas (10 ${ }^{\text {th }}$ March-16 $6^{\text {th }}$ March) during the year 2015-16. Highest number of fruit set panicle ${ }^{-1}$ was recorded in Langra (137.75) while, maximum fruit set per cent was noted in Bombai (41.07\%). Minimum days for maturity was taken by Gulabkhas (90.17 days). Maximum yield $\left(501.00 \mathrm{~kg}^{\mathrm{tree}} \mathrm{e}^{-1}\right)$ was recorded in Langra.
\end{abstract}

Keywords: Mango, cultivars, panicle, flowering, fruit set, yield

\section{Introduction}

Mango (Mangifera indica L.) is an important fruit crop of India belonging to the family Anacardiaceae. Mango is a tropical fruit tree which usually flowers in spring and produces attractive fruits. Mango inflorescence is a branched terminal panicle, up to $0.6 \mathrm{~m}$ long and has several hundred to several thousand flowers. Mango inflorescence is a flowering shoot called panicle and it bears two types of flowers, male and hermaphrodite flowers. Sex ratio is a variable component within panicles, tree and among cultivars. The initial fruit set is directly related to the proportion of perfect flowers (Singh et al., 2015).

A tree can have 200-3000 panicles with a potential to produce tremendous number of flowers (Barui and Ghosh, 2002). Cool temperature regulates the flowering in mango. However, in the absence of cool temperature, induction of flowering occur in response to water stress. Different degree of water stress during flower bud development is advantageous for good flowering (Singh and Singh, 2003). Furthermore, it has been demonstrated that the floral stimulus originates from mature leaves in mango and young leaves inhibit the floral bud initiation (Kulkarni, 1986. Hence Water stress during flower bud development in subtropical condition restricts the production of new leaves and consequently increases the proportion of flower inductive leaves (mature leaves). There is possibility that floral induction in mango can also occur after a period of plant water stress in favourable temperature, when canopies consist mainly of mature, inductive leaves. The skin is smooth, thick and commonly yellow or greenish when mature. Mango fruit develop rapidly after fruit set and is ready for harvesting within 13-20 weeks, depending upon the variety and climate. Mango is essentially a tropical fruit. It generally does well within temperature range of 24-27 ${ }^{\circ} \mathrm{C}$ but also can tolerate temperature as high as $48^{\circ} \mathrm{C}$. The requirements of water depend on the type of soil and climate, planting distance, cultivar, age of plants, developmental stages, NPK applications and weather conditions (Malik and Mitra, 2001; Reddy et al., 2001; Gawankar et al., 2010; Dhake et al., 2011). Productivity of mango is low due to several factors such as alternate bearing, fruit drop, diseases and pests. Most of the north Indian varieties, viz., Dashehari, Langra, Chausa and Bombay Green are alternate bearer, while, most of the South Indian varieties bear regularly (Pandey and Dinesh, 2010). Low productivity is the resultant effect of alternate bearing, inadequate fruit set followed by heavy fruit 
drop. In mango, flowering is influenced by weather conditions and varietal genotypes and is the most important trait as it finally influences the yield.

Mango belongs to the group of plants, in which an antagonism between vegetative vigour and flowering intensity is observed. Therefore, any factor that reduces the vegetative vigour, without altering the metabolic activity, favours flowering. Mango trees are generally induced to flower between october to december in northern hemisphere and during June to August in southern hemisphere. However, irregularity of flowering in mango, which varies in time and intensity of flowering from year to year to almost complete biennial (alternate flowering habit), is not an uncommon phenomenon. Accordingly, the unravelling of the nature of flower triggering and signalling elements is of utmost importance (Narvariya et al., 2015).

Even in the same region, different environmental conditions at different years can affect maturity and quality of the fruit (Devilliers, 1998). Therefore, evaluation of different promising mango cultivars for a given set of ecology is one of the prerequisite for successful mango cultivation.

\section{Materials and Methods}

The present field experiment was conducted at Horticulture Unit, Department of Horticulture, Institute of Agricultural Sciences, Banaras Hindu University, Varanasi, U.P., India during the year 2014-15 and 2015-16. The experimental orchard comes under the Indo-gangetic alluvial track in eastern Uttar Pradesh in class II of land capability class and irrigated by tube well. Varanasi is situated in eastern part of Utter Pradesh, which lies between $25^{\circ} 19^{\prime} 59^{\prime \prime} \mathrm{N}$ latitude and $83^{\circ} 00^{\prime} 00^{\prime \prime} \mathrm{E}$ longitude at an elevation of $76.80 \mathrm{~m} \mathrm{MSL}$. The mean annual rainfall is about $850-1100 \mathrm{~mm}$. The experiment was carried out on healthy and bearing of 20 years old trees.

The number of treatments were eleven and replicated thrice. Therefore, altogether thirty-three plants were selected for this investigation. Amrapali, Langra, Dashehari, Mallika, Chausa, Fazli, Bombai, Himsagar, Sepiya, Alphonso and Gulabkhas cultivars were taken for study as treatments. The experiment was laid out in Randomized Block Design (RBD). The observations were recorded on flowering characteristics as date of panicle emergence, panicle length $(\mathrm{cm})$, panicle breadth $(\mathrm{cm})$, date of flowering, number of flowers panicle ${ }^{-1}$ and duration of flowering. Fruiting characteristics and yield attributes were also recorded as date of fruit set, number of fruit set panicle ${ }^{-1}$, fruit set per cent, fruit maturity (days) and yield $\left(\mathrm{kg} \mathrm{tree}^{-1}\right)$.

\section{Results and Discussion}

\subsection{Panicle emergence and size}

\subsubsection{Date of panicle emergence}

It was found from the data presented in Table 1 that date of panicle emergence in different mango cultivars varied in both the years. It was observed that the panicle emergence was earlier in Gulabkhas and late in Fazli in both the years. The variation in flowering behavior may be attributed to the genetic variation responding to the climatic conditions. Panicles initiation in all the cultivars started from the south side of the plant. This seems to be due to more exposure of south side of the plant to sunlight hence becoming warmer than all other directions. This warmness might be the cause of earliest panicle initiation at the South side in various cultivars.

Table 1: Data regarding date of panicle emergence and size of panicles of different mango cultivars

\begin{tabular}{|c|c|c|c|c|c|c|c|c|}
\hline \multirow{2}{*}{$\begin{array}{l}\text { Treatment } \\
\text { (Cultivars) }\end{array}$} & \multicolumn{2}{|c|}{ Date of panicle emergence } & \multicolumn{3}{|c|}{ Length of panicle $(\mathrm{cm})$} & \multicolumn{3}{|c|}{ Breadth of panicle $(\mathrm{cm})$} \\
\hline & $2014-15$ & $2015-16$ & 2014-15 & $2015-16$ & $\begin{array}{c}\text { Pooled } \\
\text { mean }\end{array}$ & $2014-15$ & $2015-16$ & $\begin{array}{c}\text { Pooled } \\
\text { mean }\end{array}$ \\
\hline Amrapali & Feb13-Feb 18 & Feb 10-Feb 16 & 24.15 & 25.24 & 24.70 & 15.37 & 14.99 & 15.18 \\
\hline Langra & Feb 18-Feb 23 & Feb 20-Feb 24 & 30.34 & 29.38 & 29.86 & 21.23 & 19.17 & 20.20 \\
\hline Dashehari & Feb 12-Feb 16 & Feb 11-Feb 18 & 24.94 & 26.66 & 25.80 & 16.06 & 15.79 & 15.92 \\
\hline Mallika & Feb 8-Feb 15 & Feb 10-Feb 17 & 25.13 & 26.01 & 25.57 & 15.06 & 15.21 & 15.14 \\
\hline Chausa & Feb 27-March 3 & Feb 24-March 3 & 35.60 & 34.78 & 35.19 & 23.29 & 26.23 & 24.76 \\
\hline Fazli & Feb 28-March 7 & Feb 27-March 4 & 29.89 & 28.25 & 29.07 & 15.05 & 15.57 & 15.31 \\
\hline Bombai & Feb 2-Feb 7 & Feb 4-Feb 8 & 27.03 & 28.54 & 27.79 & 15.79 & 15.37 & 15.58 \\
\hline Himsagar & Feb 13-Feb 17 & Feb 11-Feb 19 & 27.48 & 28.97 & 28.22 & 16.26 & 15.85 & 16.06 \\
\hline Sepiya & Feb 28-March 5 & Feb 26-March 2 & 30.95 & 32.99 & 31.97 & 15.07 & 14.40 & 14.74 \\
\hline Alphonso & Feb 14-Feb 17 & Feb 16-Feb 20 & 25.93 & 27.91 & 26.92 & 23.25 & 22.28 & 22.77 \\
\hline Gulabkhas & Feb 1-Feb 5 & Feb 3-Feb 8 & 25.77 & 28.31 & 27.04 & 16.42 & 15.59 & 16.00 \\
\hline SEm \pm & & & 1.80 & 1.62 & 19.67 & 0.66 & 0.36 & 0.38 \\
\hline $\operatorname{CD}(p=0.05)$ & & & 5.31 & 4.79 & 4.95 & 1.96 & 1.07 & 1.12 \\
\hline
\end{tabular}


The results corroborated with the findings by Kanpure et al. (2009); Asif et al. (2002); Majumder et al. (2011); Kumar et al. (2014); Makhmale et al. (2015); Ghavale et al. (2016).

\subsubsection{Size of panicles}

From the experiment, it was recorded that Chausa produced maximum panicle length $(35.19 \mathrm{~cm})$. Whereas, Amrapali produced minimum panicle length $(24.70 \mathrm{~cm})$. Maximum breadth of panicle was recorded in Chausa $(24.76 \mathrm{~cm})$. Likewise, the minimum breadth of panicle recorded in Sepiya $(14.74 \mathrm{~cm})$. The variation in panicle size might be due to response of trait to environmental condition. Kumar and Jaiswal (2004) stated that possible cause of difference in panicle length and width may be due to environmental conditions. The results were in accordance with the findings of Majumder et al. (2011); Kundu et al. (2009).

\subsection{Flowering characteristics}

\subsubsection{Date of flowering}

Table 2 showed earliest flowering in cultivar Gulabkhas (Feb 17-Feb 26) in the year 2014-15 whereas in the year 2015-16, earliest flowering was observed in cultivar Bombai (Feb 20Feb 28). Flowering was very late in cultivar Sepiya for both the years. Time of flowering is an important parameter since it affects time of maturity, which in turn relates to the marketing of any commodity. Most of the time, the commodity coming into the market very early or late attracts the consumers and offers higher price to the growers (Iqbal et al., 2012). The similar observations were also noted by Chanana et al. (2005).

\subsubsection{No. of flowers panicle ${ }^{-1}$}

It was clearly observed that there was significant difference in number of flowers produced panicle ${ }^{-1}$. Maximum number of flowers was observed in Langra (1839.13). Variation in number of flowers panicles ${ }^{-1}$ attributed to inherent genetic differences of the mango cultivars. The result obtained in the present study coincide with the results of Thimmappaiah and Suman (1987), Kumar and Jaiswal (2004); Mukherjee (1953); Asif et al. (2002).

\subsubsection{Duration of flowering}

The duration of flowering varied from 22.50-36.00 days in different mango cultivars. Maximum value in terms of days was observed with Sepiya (36 days) while it was minimum (22.50 days) in case of Alphonso. The variation in flowering behavior may attribute to the genetic characters and the

Table 2: Data regarding flowering characteristics of different mango cultivars

\begin{tabular}{lllcccccc}
\hline $\begin{array}{l}\text { Treatment } \\
\text { (Cultivars) }\end{array}$ & \multicolumn{2}{l}{ Date of start of flowering } & \multicolumn{2}{c}{ No. of flowers per } & panicle & \multicolumn{3}{c}{ Duration of flowering (days) } \\
\cline { 2 - 8 } & 2014-15 & 2015-16 & $2014-15$ & $2015-16$ & $\begin{array}{c}\text { Pooled } \\
\text { mean }\end{array}$ & $\begin{array}{c}2014-15 \\
\text { 2015- } \\
\text { 16 }\end{array}$ & $\begin{array}{c}\text { Pooled } \\
\text { mean }\end{array}$ \\
\hline Amrapali & Feb 26-Feb 28 & Feb 22-Feb 25 & 941.50 & 968.00 & 954.75 & 29.00 & 27.33 & 28.17 \\
Langra & March 10-March 15 & March 9-March 15 & 1817.67 & 1860.58 & 1839.13 & 28.33 & 30.33 & 29.33 \\
Dashehari & March 3-March 8 & March 1-March 6 & 1391.67 & 1362.25 & 1376.96 & 26.67 & 31.67 & 29.17 \\
Mallika & Feb 28-March 7 & Feb 24-March 7 & 1207.92 & 1249.25 & 1228.58 & 31.33 & 29.00 & 30.17 \\
Chausa & March 12-March 18 & March 5-March 12 & 1124.58 & 1183.58 & 1154.08 & 32.67 & 33.67 & 33.17 \\
Fazli & March 6-March 17 & March 4-March 15 & 1053.92 & 1054.17 & 1054.04 & 34.67 & 34.67 & 34.67 \\
Bombai & Feb 22-Feb 25 & Feb 20-Feb 28 & 1051.50 & 1009.83 & 1030.67 & 26.67 & 32.67 & 29.67 \\
Himsagar & Feb 27-March 2 & Feb 20-March 5 & 1132.42 & 1182.42 & 1157.42 & 34.33 & 31.33 & 32.83 \\
Sepiya & March 8-March 17 & March 17-March 23 & 1304.92 & 1351.58 & 1328.25 & 36.67 & 35.33 & 36.00 \\
Alphonso & Feb 25-Feb 28 & Feb 23-Feb 27 & 974.75 & 946.75 & 960.75 & 20.67 & 24.33 & 22.50 \\
Gulabkhas & Feb 17-Feb 26 & Feb 21-Feb 25 & 1012.58 & 948.58 & 980.58 & 24.33 & 21.67 & 23.00 \\
SEm \pm & & & 21.47 & 27.06 & 14.54 & 3.05 & 2.64 & 2.51 \\
CD ( $p=0.05)$ & & & 63.33 & 79.84 & 42.91 & 8.99 & 7.80 & 7.42 \\
\hline
\end{tabular}

climatic condition. These results are in close association with Hoda et al. (2003), Kanpure et al. (2009), Majumder et al. (2011); lqbal et al. (2012).

\subsection{Fruiting characteristics}

3.3.1. Date of fruit set, fruit set no. panicle $e^{-1}$ and fruit set $\%$

The data presented in Table 3 showed that date of fruit set ranged from $11^{\text {th }}$ March- $8^{\text {th }}$ April. The results obtained in the present study coincide with the results of Anjum et al. (1999) and Hoda et al. (2003). Maximum fruit set was recorded in Langra (137.75). On the other hand, minimum fruit set was recorded in Alphonso (27.84). Maximum fruit set was noted in Bombai (41.07\%). Likewise, minimum fruit set was obtained in Fazli (24.11\%). Singh (1990) support these findings and according to him Fruit set is a varietal character depending upon several factors such as time of flowering, sex ratio, efficient cross pollination and intensity of drop. He further added that varieties differed from one another in 


\begin{tabular}{|c|c|c|c|c|c|c|c|c|c|c|c|}
\hline \multirow{2}{*}{$\begin{array}{l}\text { Treatment } \\
\text { (Cultivars) }\end{array}$} & \multicolumn{2}{|c|}{ Date of fruit set } & \multicolumn{3}{|c|}{ No. of fruit set panicle ${ }^{-1}$} & \multicolumn{3}{|c|}{ Fruit set (\%) } & \multicolumn{3}{|c|}{ Fruit maturity (days) } \\
\hline & 2014-15 & 2015-16 & $\begin{array}{c}2014- \\
15 \\
\end{array}$ & $\begin{array}{c}2015- \\
16 \\
\end{array}$ & $\begin{array}{l}\text { Pooled } \\
\text { mean }\end{array}$ & $\begin{array}{c}2014- \\
15 \\
\end{array}$ & $\begin{array}{c}2015- \\
16 \\
\end{array}$ & $\begin{array}{c}\text { Pooled } \\
\text { mean }\end{array}$ & $\begin{array}{c}2014- \\
15 \\
\end{array}$ & $\begin{array}{c}2015- \\
16 \\
\end{array}$ & $\begin{array}{c}\text { Pooled } \\
\text { mean }\end{array}$ \\
\hline Amrapali & $\begin{array}{l}\text { March 15- } \\
\text { March } 19\end{array}$ & $\begin{array}{l}\text { March 17- } \\
\text { March } 20\end{array}$ & 68.84 & 72.52 & 70.68 & 38.18 & 36.44 & 37.31 & 114.33 & 111 & 112.67 \\
\hline Langra & $\begin{array}{l}\text { March 24- } \\
\text { March } 29\end{array}$ & $\begin{array}{l}\text { March 20- } \\
\text { March } 26\end{array}$ & 135.38 & 140.11 & 137.75 & 31.23 & 29.4 & 30.31 & 96.33 & 100.33 & 98.33 \\
\hline Dashehari & $\begin{array}{l}\text { March 24- } \\
\text { March } 26\end{array}$ & $\begin{array}{l}\text { March 22- } \\
\text { March } 27\end{array}$ & 98.66 & 108.39 & 103.52 & 39.22 & 39.58 & 39.4 & 112.33 & 109.67 & 111 \\
\hline Mallika & $\begin{array}{l}\text { March 26- } \\
\text { April } 3\end{array}$ & $\begin{array}{l}\text { March } 23- \\
\text { April } 7\end{array}$ & 80.45 & 80.55 & 80.5 & 37.83 & 35.2 & 36.52 & 109 & 106.67 & 107.83 \\
\hline Chausa & $\begin{array}{l}\text { March 29- } \\
\text { April } 6\end{array}$ & $\begin{array}{l}\text { March } 23- \\
\text { April } 4\end{array}$ & 77.37 & 77.85 & 77.61 & 34.39 & 33.09 & 33.74 & 135.67 & 132 & 133.83 \\
\hline Fazli & $\begin{array}{l}\text { March 28- } \\
\text { April } 8\end{array}$ & $\begin{array}{l}\text { March } 30- \\
\text { April } 6\end{array}$ & 58.42 & 65.99 & 62.2 & 23.54 & 24.67 & 24.11 & 130.33 & 134.67 & 132.5 \\
\hline Bombai & $\begin{array}{l}\text { March } 12- \\
\text { March } 16\end{array}$ & $\begin{array}{l}\text { March } 11 \text { - } \\
\text { March } 14\end{array}$ & 78.89 & 82.66 & 80.77 & 42.01 & 40.13 & 41.07 & 91.33 & 93.33 & 92.33 \\
\hline Himsagar & $\begin{array}{l}\text { March 19- } \\
\text { March } 26\end{array}$ & $\begin{array}{l}\text { March } 17- \\
\text { March } 23\end{array}$ & 59.52 & 71.99 & 65.76 & 33.52 & 37.53 & 35.53 & 113.67 & 111.33 & 112.5 \\
\hline Sepiya & $\begin{array}{l}\text { March } 28- \\
\text { April } 7\end{array}$ & $\begin{array}{l}\text { March } 26 \\
\text {-April } 8\end{array}$ & 110.91 & 112.32 & 111.61 & 35.3 & 36.66 & 35.98 & 132.67 & 137.67 & 135.17 \\
\hline Alphonso & $\begin{array}{l}\text { March 18- } \\
\text { March } 26\end{array}$ & $\begin{array}{l}\text { March } 21 \text { - } \\
\text { March } 28\end{array}$ & 26.75 & 28.93 & 27.84 & 27.58 & 28.52 & 28.05 & 96 & 94.33 & 95.17 \\
\hline Gulabkhas & $\begin{array}{l}\text { March } 13- \\
\text { March } 15\end{array}$ & $\begin{array}{l}\text { March } 10- \\
\text { March } 16\end{array}$ & 58.95 & 59.99 & 59.47 & 32.89 & 30.98 & 31.94 & 89.67 & 90.67 & 90.17 \\
\hline SEm \pm & & & 3.41 & 1.46 & 3.41 & 1.86 & 1.31 & 1.35 & 5.34 & 4.26 & 4.17 \\
\hline$C D(p=0.05)$ & & & 10.07 & 4.3 & 10.07 & 5.5 & 3.87 & 3.99 & 15.76 & 12.59 & 12.31 \\
\hline
\end{tabular}

these respects and this lead to varying fruit set in different varieties. Singh (1988) also supported this and stated that weather conditions also affected fruit set.

\subsubsection{Fruit maturity (days)}

Sepiya took more days to maturity (135.17) while, minimum days for maturity was taken by Gulabkhas (90.17). The difference in maturity of fruits of different cultivars might be due to the difference in date of panicle emergence and prevailing environmental conditions, besides their genetic makeup (Kundu et al., 2009). Variation in fruit maturity in different varieties might be due to change in location or inherent genetic variation (Singh, 2002 and Hoda et al., 2003). Similar findings had also reported by Sardar et al.(1998) and Majumder et al. (2011).

\subsection{Yield attributes ( $\left.\mathrm{kg}_{\mathrm{tree}} \mathrm{e}^{-1}\right)$}

There was significant difference obtained in yield in different cultivars (Figure 1). It is clearly indicated from Graph 1 that maximum yield tree ${ }^{-1}$ was found in Langra (501.00 $\mathrm{kg}^{\text {tree }} \mathrm{e}^{-1}$ ) while, minimum yield tree ${ }^{-1}$ was observed in Gulabkhas (92.66 $\left.\mathrm{kg} \mathrm{tree}^{-1}\right)$. It might be due to varietal differences. The findings

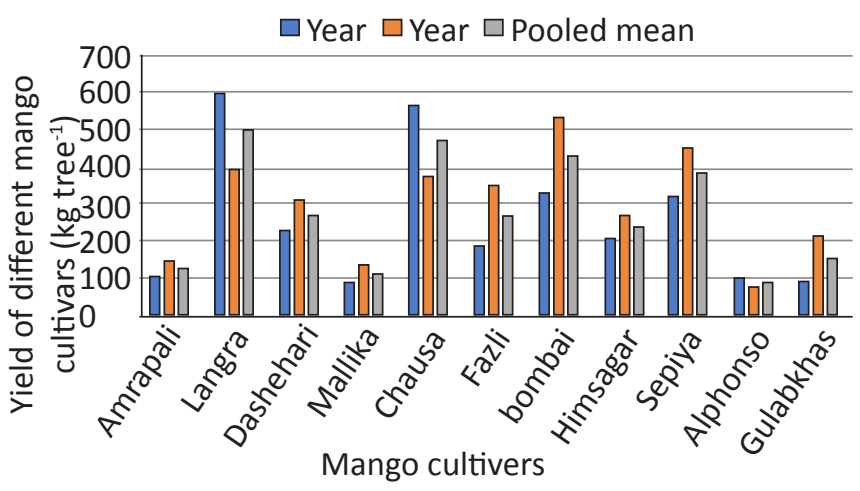

Figure 1: Yield of different mango cultivars $\left(\mathrm{kg} \mathrm{tree}^{-1}\right)$

of this study are supported by the idea that yield is highly variable factor depending upon the cultivars and age of plants, climatic conditions, incidence of pests and diseases. Majority of the workers had the idea that yield potential was a varietal character. The increase in yield in terms of weight might be either due to the large sized fruits or due to more number 
of fruits per plant ${ }^{-1}$. Similar results were obtained by Kumar and Singh (2005), Sinha et al., (2007) and Kundu et al. (2009).

\section{Conclusion}

The cultivar Langra showed the higher per cent of flowering, fruiting and yield under Indo-gangetic plains of Uttar Pradesh.

\section{References}

Anjum, M.A., Chattha, G.A., Sultan, M., Abbas, S., 1999. Studies on flowering behaviour, fruit setting and extent of floral malformation in different cultivars of mango (Mangifera indica L.). International Journal of Agricultural and Biology 3(1), 46-49.

Asif, M., Usman, M., Jaskani, M.J., Khan, M.M., 2002. Comparative study of flower, sex ratio in different cultivars of mango (Mangifera indica L.). International Journal of Agricultural and Biology 4(2), 220-222.

Barui, F.K., Ghosh, S.N., 2002. Performance of different available mango cultivars for semi-arid region of West Bengal. Environment and Ecology 20(3), 588-592.

Chanana, Y.R., Josan, J.S., Arora, P.K., 2005. Evaluation of some mango cultivars under North Indian conditions. In Proceedings of International Conference on Mango and Date Palm: Culture and Export 20-23 $3^{\text {rd }}$ June 2005, 34-38.

Devilliers, E.A., 1998. The cultivation of mango. Institute of Tropical and Subtropical Fruits, 28-30.

Dhake, A.V., Moitro, P., Karangle, B.T., 2011. Performance of mango cultivars. Acta Horticulturae 509, 107-112.

Gawankar, M.S., Solvi, B.R., Charan, S.A., Palvi, N.Y., 2010. Performance of mango varieties. Journal of Horticultural Sciences 5(2), 114-116.

Ghavale, S.L., Pujari, K.H., Patil, R.S., 2016. Studies on the effect of pruning on flowering behaviour of mango $\mathrm{cv}$. Alphonso. International Journal of Tropical Agriculture 34(4), 991-996.

Hoda, M.N., Singh, S., Singh, J., 2003. Evaluation of mango (Mangifera indica L.) cultivars for quality attributes. Indian Journal of Agricultural Sciences 73(9), 504-506.

Iqbal, M., Niamatullah, M., Hussain, A., Munir, M., Khan, I., Khan, M.Q., 2012. Performance of selected parameters of mango cultivars in Muzaffargarh district, Pakistan. Sarhad Journal of Agriculture 28(3), 395-398.

Kanpure, R.N., Singh, H.P., Reja, R.K., 2009. Evaluation of mango hybrids for Kymore Plateau of Madhya Pradesh. Journal of Community Mobilization and Sustainable Development 4(2), 1-3.

Kulkarni, V.J., 1986. Further studies on graft-induced off season flowering and fruiting in mango (Mangifera indica L.). Journal of Horticultural Science 63, 361-367.

Kumar, M., Ponnuswami, V., Kumar, P.J., Saraswathy, S., 2014. Influence of season affecting flowering and physiological parameters in mango. Scientific Research and Essays 9(1), 1-6.

Kumar, N., Jaiswal, U.S., 2004. Bearing behaviour of some
South and West India mangoes and its vegetative growth. Haryana Journal of Horticultural Sciences 33(1/2), 9-10.

Kumar, R., Singh, S., 2005. Evaluation of mango genotypes for flowering, fruiting and fruit quality attributes. The Orissa Journal of Horticulture 33(1), 77-79.

Kundu, S., Sanyal, N., Datta, P., 2009. Studies on potentiality of some mango varieties in West Bengal. Journal of Crop and Weed 5(2), 68-71.

Majumder, D.A.N., Hassan, L., Rahim, M.A., Kabir, M.A., 2011. Studies on physiomorphology, floral biology and fruit characteristics of mango. Journal of the Bangladesh Agricultural University 9(2), 187-199.

Makhmale, S., Makwana, A.N., Barad, A.V., Nawade, B.D., 2015. Physiology of flowering. The case of mango. International Journal of Applied Research 1(11), 1008-1012.

Malik, S., Mitra, S.K., 2001. Studies on physico-chemical characteristics of nineteen mango cultivars grown in west Bengal. Indian Agriculturist 45(3/4), 21-29.

Mukherjee, S.K., 1953. The Mango-its botany, cultivation, uses and future improvements. Economic Botany 7, 130-162.

Narvariya, S.S., Dhami, V., Singh, C.P., Kumar, K., 2015. Efficacy of cultar on growth, flowering and yield behaviour of mango (Mangifera indica L.) cv. Dashehari. Environment and Ecology 33(2A), 827-831.

ICAR. 2010.Pandey, S.N., Dinesh, M.R., 2010. Mango, Indian Council of Agricultural Research, New Delhi, 30-97.

Reddy, C.H., Prasad, P.P.R., Umamaheswari, T., 2001. Screening of mango cultivar against the leaf webber Orthaga exvinacea Hampson (Pyralidae:Lepidoptera). Indian Journal of Plant Protection 29(1/2), 118-120.

Sardar, P.K., Hossain, M.A., Islam, M.S., Khondaker, S.M.A.T., 1998. Studies on thephysico-morphological characters of some popular mango cultivars. Bangladesh Journal of Agricultural Sciences 25(1), 1-4.

Singh, A., Singh, C.P., Singh, A.K., 2015. Flowering behaviour of mango genotypes under tarai conditions of Uttarakhand. International Journal of Basic and Applied Agricultural Research 13(3), 400-406.

Singh, R., 1988. Fruits. National Book Trust, New Delhi, 18-48. Singh, R.N., 1990. Mango. I.C.A.R, Krishi Anusandhan Bhavan, Pusa, New Delhi, 21-23.

Singh, S., 2002. Evaluation of mango cultivars for their flowering, fruiting and fruit quality attributes. Progressive Horticulture 34(2), 240-243.

Singh, V.K., Singh, A., 2003. Effect of paclobutrazol on regularity of bearing in mango (Mangifera indica). Physiology and Molecular Biology of Plants 9(2), 239-248.

Sinha, B., Singh, U.K., Kumar, N., 2007. Fruit quality of leading late varieties of mango. The Orissa Journal of Horticulture 35(2), 84-86.

Thimmappaiah Suman, C.L., 1987. Sex in relation to fruit set and fruit yield in mango.The Punjab Horticultural Journal 27, 8-11. 